\title{
Determination of the Absolute Configuration of (+)- Surinamensin's via Diastereomeric O-Methylmandelic Esters
}

\author{
Lourival da S. Santos \\ Universidade Federal do Pará - Departamento de Química \\ - CCEN - 6600 - Belém - PA - Brasil. \\ Lauro E. S. Barata* \\ Universidade Estadual de Campinas - Instituto de Química \\ - 13081 - Campinas - SP - Brasil.
}

Received: September 20, 1989; December 4, 1989

A configuração absoluta da (+)-surinamensina 1a, uma neolignana 8.0.4', foi determinada baseado em seus esteres do ácido $O$-metilmandélico.

The absolute configuration of (+)-surinamensin 1a, a 8.0.4' neolignan, has been determined based on its $O$-methylmandelates esters.

Key words: surinamensin, O-methylmandelate, absolute configuration

\section{Introduction}

While working on the leaves of Virola surinamensis (Rol.) Warb. a typical Amazonian tree, the hexane crude extract was submitted to biological essays revealing a strong activity against Schistosoma mansoni cercariae infestation ${ }^{1}$. A careful monitoring of the chromatographic fractions activity led to the isolation of a 8.0.4' neolignan, named surinamensin $1 \mathrm{a}$ which was the secondary metabolite responsible for the above mentioned activity.

Synthetic work supported the structural proposal and the $\mathrm{C}-7 / \mathrm{C}-8$ relative configuration was assigned as threo based on ${ }^{1} \mathrm{H}-\mathrm{nmr} r^{2}$ and ${ }^{13} \mathrm{C}-\mathrm{nmr}^{3}$. The absolute configuration, though, remained undetermined.

In this paper we report the absolute configuration of $(+)$-surinamensin 1a using the method of $O$ methylmandelate derivatives ${ }^{4}$.<smiles>C/C=C/c1ccc(O[C@H](C)[C@H](O)c2cc(OC)c(OC)c(OC)c2)c(OC)c1</smiles><smiles>C/C=C/c1ccc(OC(C)C(O)c2cc(OC)c(OC)c(OC)c2)c(OC)c1</smiles>

1 - threo<smiles>C/C=C/c1ccc(O[C@H](C)[C@H](O)c2cc(OC)c(OC)c(OC)c2)c(OC)c1</smiles>

la 
Table 1. 'H-NMR spectra of diastereomeric esters $\mathbf{2 a}$ and $\mathbf{2} \mathbf{b}^{a}$

\begin{tabular}{|c|c|c|}
\hline \multirow[t]{2}{*}{ PROTON } & \multicolumn{2}{|c|}{ COMPOUND } \\
\hline & $2 \mathbf{a}$ & $\mathbf{2 b}$ \\
\hline $\mathrm{CH}_{3}-9$ & $0.98(\mathrm{~d}, \mathrm{~J}=7.0)$ & $1.11(\mathrm{~d}, \mathrm{~J}=7.0)$ \\
\hline $\mathrm{CH}_{3}-9^{\prime}$ & $1.88(\mathrm{~d}, \mathrm{~J}=5.0)$ & $1.88(\mathrm{~d}, J=5.0)$ \\
\hline $\mathbf{O C H}_{3}-(\mathrm{OMMA})$ & $3.39\left(\mathrm{~s}, 1 \mathbf{O C H}_{3}\right)$ & $3.33\left(\mathrm{~s}, 1 \mathbf{O C H}_{3}\right)$ \\
\hline \multirow[t]{3}{*}{$\mathbf{O C H}_{3} \operatorname{Ar}(\mathrm{A})(\mathrm{B})$} & $\left.3.78(\mathrm{~s}, \mathbf{3 O C H})_{3}\right)$ & $3.62\left(\mathrm{~s}, 1 \mathbf{O C H}_{3}\right)$ \\
\hline & $3.82\left(\mathrm{~s}, 1 \mathbf{O C H}_{3}\right)$ & $3.78\left(\mathrm{~s}, 2 \mathbf{O C H}_{3}\right)$ \\
\hline & & $3.82\left(\mathrm{~s}, 1 \mathbf{O C H}_{3}\right)$ \\
\hline $\mathrm{H}-7$ & $5.91(\mathrm{~d}, J=6.0)$ & $5.88(\mathrm{~d}, \mathrm{~J}=6.0)$ \\
\hline H - 8 & $4.30-4.70(\mathrm{~m})$ & $4.30-4.70(\mathrm{~m})$ \\
\hline $\mathrm{OCH}_{3}-\mathrm{C}-\mathrm{H}(\mathrm{Ph})^{\mathrm{b}}$ & $4.81(\mathrm{~s})$ & $4.62(\mathrm{~s})$ \\
\hline $\mathrm{H}-7$ & $6.37(\mathrm{~d}, \mathrm{~J}=16.0)$ & $6.37(\mathrm{~d}, \mathrm{~J}=16.0)$ \\
\hline $\mathrm{H}-8^{\prime}$ & $6.00-6.30(\mathrm{~m})$ & $6.00-6.30(\mathrm{~m})$ \\
\hline $\mathrm{H}-\mathrm{Ar}(\mathrm{A})$ & $6.57(\mathrm{~s})$ & $6.30(s)$ \\
\hline $\mathrm{H}-\mathrm{Ar}(\mathrm{B})$ & $6.70-6.90(\mathrm{~m})$ & 6.89 (br s) \\
\hline $\mathrm{H}-\operatorname{Ar}(\mathrm{C})$ & $7.10-7.60(\mathrm{~m})$ & $7.30(\mathrm{~s})$ \\
\hline
\end{tabular}

a. Chemical shifts were determined at $80 \mathrm{MHz}$ in $\mathrm{CDCP}_{3} . \delta$ values are in ppm downfield in relation to TMS. The J values are given in $\mathrm{Hz}$. ${ }^{b}$ Proton of the O-methylmandelic portion.

\section{Experimental}

Optical rotations were measured with a Polamat polarimeter. The IR spectra were obtained on a Perkin Elmer 399B spectrophotometer. ${ }^{1} \mathrm{H}-\mathrm{NMR}$ spectra were recorded in $\mathrm{CDCP}_{3}$, using TMS as internal standard, employing a Brucker AW-80 NMR spectometer. Low resolution mass spectra were obtained with Varian MAT 311A instrument, operating at $70 \mathrm{eV}$. Analytical and preparative TLC were carried out on precoated Merck silica gel F 254 plates. Compounds were visualized by uv light or spraying with anisaldehyde followed by heating.

(S)-OMMA-7S,8S-surinamensin 2a and (S)-OMMA-7R, $8 R$-surinamensin $2 \mathrm{~b}$ : (S)-O-methylmandelic acid $(0.24 \mathrm{~g}$, $1.54 \mathrm{mmol}$ ) was added to a white suspension prepared by the slow addition of oxalyl chloride $(0.14 \mathrm{~m} \ell, 1.6 \mathrm{mmol})$ to dry DMF $(0.18 \mathrm{~m} \ell, 2.17 \mathrm{mmol})$ in dry acetonitrile $(5 \mathrm{m \ell})$ at $0^{\circ} \mathrm{C}$ under nitrogen. After $10 \mathrm{~min}$, a solution of threo$( \pm)$-surinamensin $(0.20 \mathrm{~g}, 0.51 \mathrm{mmol})$ in dry pyridine $(0.26$ $\mathrm{m} \ell, 3.2 \mathrm{mmol}$ ) was slowly added during 3 -min and the resulting mixture was stirred at $0^{\circ} \mathrm{C}$ for $1 \mathrm{hr}$. The reaction mixture was diluted with diethylether $(25 \mathrm{ml})$ and the organic phase washed twice with a satured aqueous cupric sulfate solution and dried over anhydrous sodium sulfate. The solvent was removed under reduced pressure to give a pale yellow oil. Purification by flash collumn chromatography on silica gel (hexane: diethylether, $2: 8$ ) gave $0.244 \mathrm{~g}(90 \%$ yield) of two diastereomeric esters $2 \mathrm{a}$ (less polar) and $\mathbf{2 b}$ (more polar) in 1:1 ratio by HPLC analysis. The diastereomers were separated by preparative thin layer chromatography (hexane: diethylether, 4: 6) with continuous elution.

2a: colorless oil, $[\alpha]_{D}^{22}+17.8^{\circ}\left(c 0.30, \mathrm{CHCl}_{3}\right)$; IR (film) $\nu_{\max } 2940,2880,1750(\mathrm{C}=\mathrm{O}$, ester $), 1600,1515,1465$, $1455,1330,1260,1130,1010,910,830 \mathrm{~cm}^{-1}$; ${ }^{1} \mathrm{H}-\mathrm{NMR}$ $\left(80 \mathrm{MHz}\left(\mathrm{CDC} \ell_{3}\right)\right.$ see Table 1 .

2b: colorless oil, $[\alpha]_{\mathrm{D}}^{22}-14.8^{\circ}\left(c 0.53, \mathrm{CHCl}_{3}\right)$.IR (film) $\nu_{\max } 2920,2825,1758,(\mathrm{C}=\mathrm{O}$, ester $), 1595,1515,1510$,
$1465,1335,1265,1130,1010,915,830 \mathrm{~cm}^{-1} ;{ }^{1} \mathrm{H}-\mathrm{NMR}$ $\left(80 \mathrm{MHz}\left(\mathrm{CDCl}_{3}\right)\right.$ see Table 1 .

(+)-7S,8S-surinamensin 1a: To a solution of $2 \mathrm{a}(0.080 \mathrm{~g}$, $0.15 \mathrm{mmol})$ in methanol $(1.0 \mathrm{~m} \ell)$ were added $\mathrm{K}_{2} \mathrm{CO}_{3}$ (anhydrous powder) $(0.084 \mathrm{~g}, 0.6 \mathrm{mmol})$ and enough $\mathrm{H}_{2} \mathrm{O}$ to obtain a nearly homogeneous solution. After $1 \mathrm{~h}$ at room temperature the reaction mixture was extracted with $\mathrm{CH}_{2} \mathrm{Cl}_{2}(3 \times 5 \mathrm{~m} \ell)$. The organic layer was washed with $\mathrm{H}_{2} \mathrm{O}$ (1x $5 \mathrm{~m} \ell$ ), dried (anhydrous $\mathrm{Na}_{2} \mathrm{SO}_{4}$ ), filtered and concentrated under reduced pressure. The crude extract was purified by preparative TLC (hexane: diethylether, $4: 6$ ) using continuos elution and gave $0.058 \mathrm{~g}(98 \%$ yield) of $(+)-7 \mathrm{~S}, 8 \mathrm{~S}$-surinamensin 1a, $[\alpha]_{\mathrm{D}}^{22}+101.2^{\circ}$ (c 0.43 , $\mathrm{CHCl}_{3}$ ), ${ }^{1} \mathrm{H}-\mathrm{NMR}$, IR and $\mathrm{ms}$ data were in accordance with those previously reported ${ }^{2}$.

$(-)-7 R, 8 R$-surinamensin $\mathbf{1 b}$ : obtained from $\mathbf{2 b}$ by the same procedure with $96 \%$ yield. $[\alpha]_{D}^{22}-97.4^{\circ}\left(c 0.49, \mathrm{CHCl}_{3}\right)$. ${ }^{1} \mathrm{H}-\mathrm{NMR}, \mathrm{IR}$ and $\mathrm{ms}$ data are identical with those of $1 \mathrm{a}$. Extraction of (+)-surinamensin la from leaves: The compound 1a was isolated from the leaves of Virola surinamensis (Rol.) Warb collected in Belém-Pará-Brazil following the procedure reported by Barata et $a l^{2}$. The last purification step however was realized by preparative TLC continuously eluted with hexane: diethylether 4:6. 1a (natural) was a viscous colorless oil $[\alpha]_{\mathrm{D}}^{23}+131.2^{\circ}(c 0.21$, $\mathrm{CHCl}_{3}$ )and ${ }^{1} \mathrm{H}-\mathrm{NMR}, \mathrm{IR}$ and $\mathrm{ms}$ data are in accordance with those reported in the literature ${ }^{2}$.

\section{Results and Conclusions}

Synthetic threo-( \pm )-surinamensin ${ }^{2,3,6}$ was treated with o-methylmandelic acid (OMMA) following Trost's method ${ }^{4}$, leading to a diastereomeric mixture which was resolved by preparative thin layer chromatography, continuously eluted with hexane-diethylether 4:6. The "less polar" component $2 \mathrm{a}$ was dextrorotatory, $[\alpha]_{\mathrm{D}}^{22}+17.8^{\circ}$ (c $0.30, \mathrm{CHCl}_{3}$ ) and had the $\mathrm{C}-9$ methyl group resonating at $0.98 \mathrm{ppm}$, while compound $\mathbf{2 b}$ was "more polar", levorotatory, $[\alpha]_{\mathrm{D}}^{22}-14.8^{\circ}\left(\mathrm{c} 0.53, \mathrm{CHCl}_{3}\right)$ and its $\mathrm{C}-9$ 


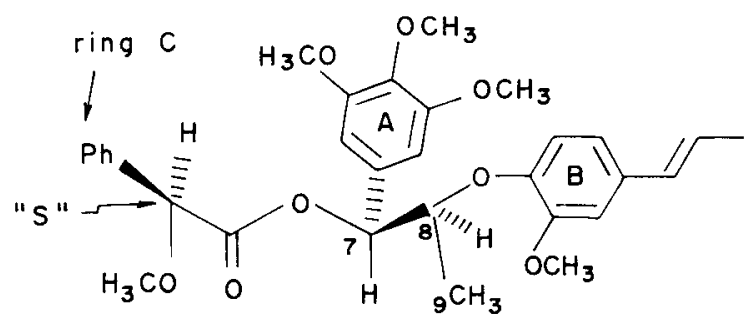

(S) - OMMA - 7S, 8S-surinamensin 2a (less polar)

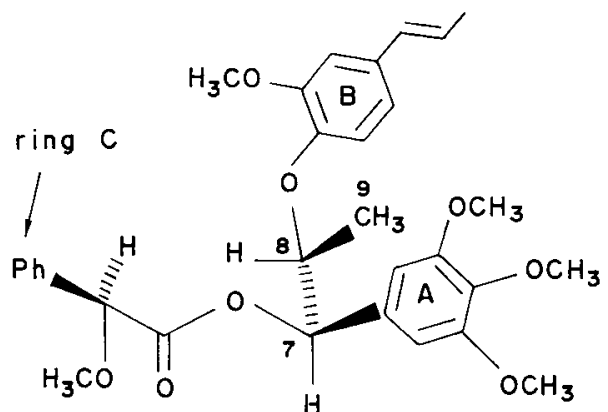

(S) - OMMA - 7R, 8R-surinamensin 2b (more polar)

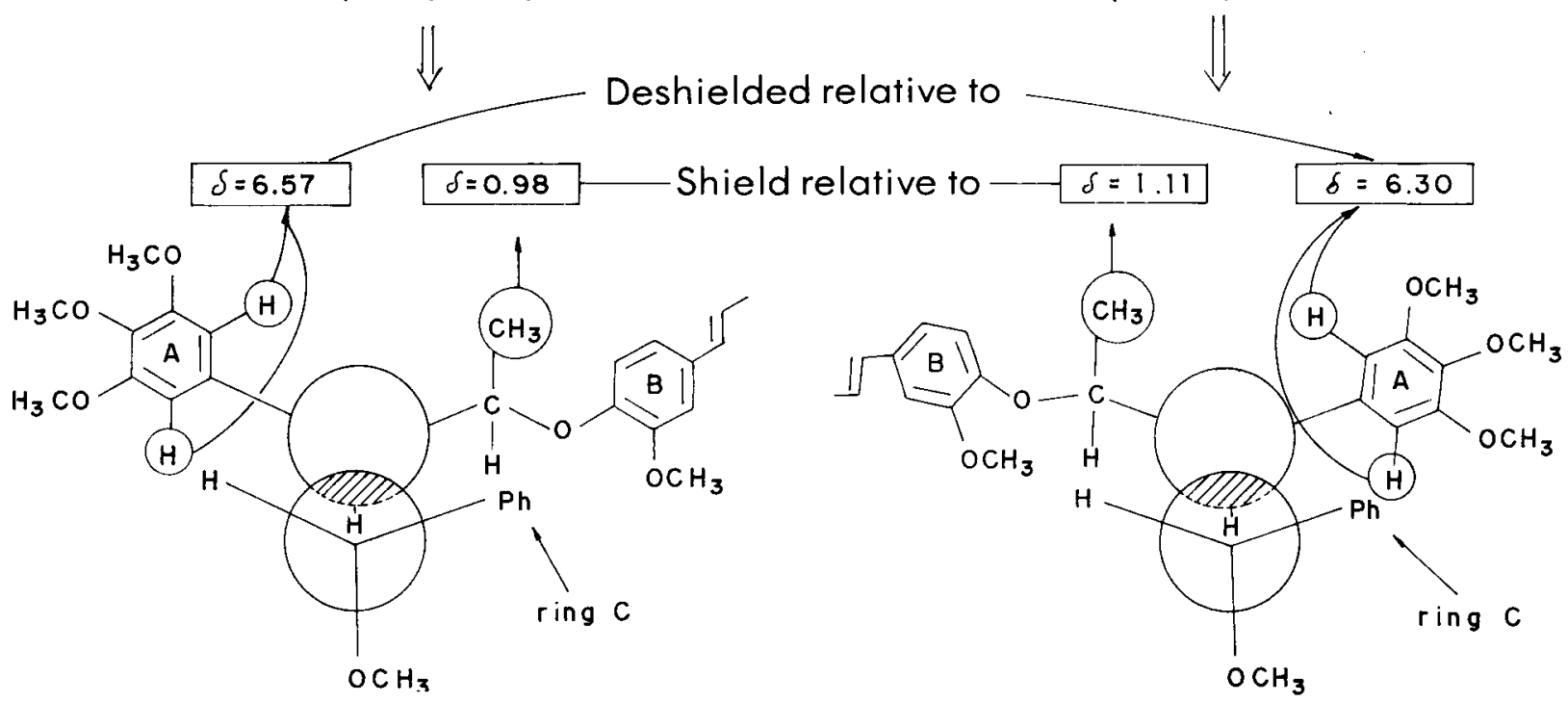

Figure 1 - Configurational correlation model for diastereomerics esters $\mathbf{2 a}$ and $\mathbf{2 b}$

methyl group absorbed at lower field, $1.11 \mathrm{ppm}$. Based on the model proposed by Trost and coworkers ${ }^{4}$ we deduced that the C-9 methyl of $2 a$ is on the same side as the aromatic moiety of the $O$-methylmandelate portion (ring $\mathbf{C}$ ), showing an upfield shift in comparison to the corresponding signal of $\mathbf{2 b}$, due to the anisotropic shielding by ring $\mathbf{C}$ (Fig. 1).

Additionally, ring $\mathbf{A}$ of $\mathbf{2 b}$ has to be located on the same side as ring $\mathbf{C}$ because its aromatic protons absorbed at a higher field $(6.30 \mathrm{ppm})$ than the corresponding ones of 2a (6.57ppm).

Consequently the absolute configuration at carbon 7 of $2 \mathbf{a}$ should be $(S)$ and at that of $2 \mathbf{b}$ should be (R). Ultimately as $\mathbf{2 a}$ and $\mathbf{2 b}$ are threo isomers we have deduced that $2 a$ is (S)-OMMA-7S, 8S-surinamensin and $2 \mathbf{b}$ is (S)OMMA-7R, 8S-surinamensin.

A mild basic hydrolysis ${ }^{5}$ of $2 \mathbf{a}$ and $2 \mathbf{b}$ led to the chiral alcohols 1a, (+)-7S, 8S-surinamensin $[\alpha]_{D}^{22}+101.2^{\circ}(c$ $\left.0.43, \mathrm{CHCl}_{3}\right)$ and $1 \mathrm{~b}(-)-7 \mathrm{R}, 8 \mathrm{R}$-surinamensin $[\alpha]_{\mathrm{D}}^{22}$ $-97.4^{\circ}$ (c $\left.0.49, \mathrm{CHCl}_{3}\right)$.

Comparasion of the optical rotations of the resolved alcohols to that of the natural product which was reisolated in a purer form, from the leaves of Virola surinamensis $[\alpha]_{\mathrm{D}}^{23}+131.2^{\circ}\left(c 0.21, \mathrm{CHCl}_{3}\right)$ led us to the conclusion that surinamensin, is $(+)-7 \mathrm{~S}-8 \mathrm{~S}, 1 \mathrm{a}$.

\section{Acknowledgments}

Our thanks to CAPES-PICD for the financial support and the fellowship of one of us (LSS), to Dr. William Rodrigues, INPA-CNPq for the botanical identification, to Pedro H. Ferri for the discussion and Mrs. Paula Pilli for the ${ }^{1} \mathrm{H}$-NMR spectra.

\section{References}

1. L.E.S. Barata and P.M. Baker, Cienc. e Cult. 25, 169 (1973).

2. L.E.S. Barata, P.M. Baker, O.R. Gottlieb and E.A. Rúveda, Phytochemistry 17783 (1978).

3. A.C.H. Braga, S. Zacchino, H. Badano, M.G. Sierra and E.A. Rúveda, Phytochemistry 23, 2025 (1984).

4. B.M. Trost, J.L. Belletire, S. Godlski, P.G. McDougal, J.M. Balkovec, J.J. Baldwin, M.E. Christy, G.S. Ponticello, S.L. Varga and J.P. Springer, J. Org. Chem. 51, 2370 (1986)

5. J.K. Whitesell and D. Reynolds. J. Org. Chem. 48, 3548 (1983).

6. S.A. Zacchino and H. Badano, J. Nat. Prod. 48, 830 (1985). 